\title{
Stock Liquidity, Feedback Prices, And Asset Liquidity: Evidence From The Tunisian Stock Market
}

\author{
Nadia Loukil, Ph.D., University of Tunis, Tunisia
}

\begin{abstract}
This paper explores how feedback prices influence firms' investment on asset liquidity through stock liquidity. Using a sample of the Tunisian listed firms between 1999 and 2010, empirical results confirm that stock market liquidity plays a significant role in investment decisions and show that high stock liquidity encourages firms to invest more on asset liquidity to overcome feedback prices (negative and positive feedback). Therefore, the paper's findings demonstrate the link between stock markets and the current business activity of the firm. Furthermore, the results indicate how stock liquidity strengthens feedback prices effects on managerial decisions and choices, which highlights the importance of stock liquidity.
\end{abstract}

Keywords: Stock Liquidity; Asset Liquidity; Feedback Prices; Emerging Markets

\section{INTRODUCTION}

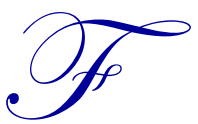

inancial theories argue that stock liquidity affects corporate financial decisions by reducing cost of capital and facilitating access to more funds on the capital markets. Hence, firms with more liquid stocks have less financial constraints and may pursue investments even if their projects are risky. Moreover, stock liquidity has a corporate governance role and reduces agency conflicts (Diamond and Verrecchia, 1982; Holmstrom and Tirole, 1993). Even so, stock liquidity may influence managerial decisions and choices through feedback from stock prices (Subrahmanyam and Titman, 2001, Fang et al. 2009). Recently, many empirical studies are interested in linking the stock liquidity to both the firms' policy and decisions. Butler et al. (2005) and Lipson and Mortal (2009), among others, examine the relationship between stock liquidity and financial decisions (debt policy and equity issuance). They confirm that firms with high liquidity level have lower issuance costs, which encourages them to use more funds like debt. In the same vein, Fang et al. (2009) find out that high stock liquidity enhances firm value.

Most previously cited papers are interested in developed markets. However, emerging markets have attracted little attention. Munoz (2013) focuses on the relationship between firm investment and stock liquidity, in Latin American firms. He finds a positive association between investment and stock liquidity which is more pronounced for firm issuing shares. Ben khediri and Daadaa (2011) provide evidence that Tunisian firms with more liquid stocks have less leverage ratio.

This article seeks to answer the following question: Does the stock liquidity influence the firms' investment in liquid assets in emerging markets like Tunisia?

This article contributes to the understanding of the relationship between market microstructure and corporate finance, in thin markets. This study adds to the existing evidence in two distinct ways. Firstly, it focuses on investment decision on liquid assets, which plays a main role in defining corporate financial policy. In other words, firms may accumulate liquid assets or cash to have more financial flexibility and meet their unanticipated contingencies if the costs of other financing resources are high (Myers and Majluf, 1984; Opler et al., 1999; Han and Qiu, 2007; Sufi, 2009; Lins et al. 2010). From the agency theory perspective, more cash leads self-interesting 
managers to make more decisions by ignoring shareholders' interests, for example over investing in non-profitable projects rather than distributing dividends. Secondly, the Tunisian stock exchange (TSE) was chosen to explore this issue because it has less market liquidity than other emerging markets. Furthermore, in spite of all reforms undertaken by Tunisian regulators, statistics of the emerging countries from $\mathrm{S} \& \mathrm{P}^{1}$ for the year 2005 reveal that this market is the least developed market in comparison to the markets of the Middle East and the North African (MENA) region. In addition, the investor protection level in the Tunisian market is ranking below other markets. When investor's protections are poor, Dittmar et al. (2003) found that some factors that generally influence cash holding, such as investment opportunities and asymmetric information, become less important. Also, they show that firms that operate in these countries tend to hold higher levels of cash.

The current study draws on a sample of 30 Tunisian listed firms between 1999 and 2010, in which the link between stock liquidity and investment in liquid assets was investigated. In fact, empirical findings provide evidence that stock liquidity boost the firms' investment in liquid assets. This finding is consistent with the theory of positive feedback prediction. Indeed, liquidity enhances prices informativeness to stakeholders and as consequence determines managerial decisions. This paper is organized as follows. Section 2 presents a survey of the literature and develops hypotheses. The sample and the methodology design are described in Section 3. The results are discussed in Section 4. Section 5 concludes the paper.

\section{LITTERATURE REVIEW AND HYPOTHESES}

The theory of positive feedback from stock prices is developed by Subrahmanyam and Titman (2001) where they investigate how feedback influences managerial decisions and choices. They argue that a stock price affects a firm's perception by its stakeholders: customers, suppliers, employees, lenders, and other stakeholders. For instance, firms with higher stock prices attract customers and employees and may have lower cost of capital. As a result, these perceptions may influence firm's managerial decisions: purchase, supply and investment decisions, which affect the firm's cash flow.

Goldstein et al. (2013) argue that when a trading frenzy arises, it affects both prices and firm cash flows, which legitimatly the worries the firm and the intervention of regulators. Indeed, fund providers make their decision to provide their funds to the firm or not, based on the assessment of the return on investment. To do this, they rely not only on their private information but also on the information aggregated by the firm's stock price in the financial market.

Since the stock price reflects the firm's financial situation in general, the firms profitability in particular, it affects decisions by various agents, such as capital providers. In actual fact, when speculators in the financial market short sell a stock, price decreases, then capital providers update downward their expectation of the firm's profitability. As a consequence, the firm's access to capital market is weakening, the firm's value decreasing and short sellers are becoming able to make a profit.

Some studies (Subrahmanyam and Titman, 2001; Khanna and Sonti, 2004 and Fang et al. 2009 among others) link the stock liquidity, feedback prices and managerial firms' decisions together. They advance that the entry of informed investors in the market is increasing with stock liquidity. Thus, informed trading makes prices more informative to investors, employees, customers and other stakeholders. This feedback effect improves firm performance by increasing operating performance on the one hand, and relaxing financial constraints on the other. Therefore, the prices' feedback is more important for liquid stocks.

Nyborg and Wang (2014) advance a positive association between cash holding and stock liquidity. They suggest that when stock liquidity increases, prices are more informative but the information may have either a positive or negative effect. If prices decrease (negative effect) firms support the high cost of capital and have more financial constraint. In this situation, firms must use their cash to limit the negative effect of prices feedback. On the contrary, if prices increase (positive effect), they reflect good information, may attract capital providers and reduce

${ }^{1}$ Statistics from Lagoarde-Segot and Lucey (2008). 
cost of capital. In such case, firms may use their cash holding to boost positive effects of price feedback by buying their own stock in the market. Therefore, the following hypothesis is stated:

\section{H1: High stock liquidity improves prices' feedback, which increases asset liquidity}

According to the pecking order theory of Myers (1984), firms are incited to establish a finance hierarchy in which internal funds are less costly and preferred to external financing. When firms suffer from information asymmetry problems, stock liquidity goes down and investors require higher stock return to compensate liquidity risk, which in turn induces a higher cost of external financing, especially the cost of equity (Amihud and Mendelsen, 1986). As a result, these firms may support high cost of external funding, which encourages them to use internal funds (cash and liquid assets). Indeed, Myers and Majluf (1984) argue that firms with high information asymmetry problems hold more liquid assets that are to be used as alternative funds.

Moreover, some studies ${ }^{2}$ discussed how stock liquidity may be an effective control mechanism. When the market is more liquid, large shareholders prefer to control the firm and enjoy the benefits of informed trading. In addition, stock liquidity may incite managers to invest cash in profitable projects and to enhance firms' performance (Edmans, 2009; Admati and Pfleiderer, 2009) if their management's compensation is tied to current stock prices. Hence, stock liquidity as a corporate governance mechanism may influence investment in liquid assets. When a firms experiences high stock liquidity, shareholders' activism is more important. This discourages managers to adopt opportunistic behavior. Consequently, high stock liquidity enhances managers' control, which reduces asset liquidity. The following hypothesis is formulated:

\section{H2: High stock liquidity reduces asset liquidity}

\section{DATA AND DESCRIPTIVE STATISTICS}

The sample initially consisted of all non-financial firms listed on Tunis Stock Exchange (TSE) during the period 1999-2010. Then (1) non common ordinary stocks, namely investment certificates and preferred stocks without voting right; (2) new listed stocks that are not traded during the previous 6 months to remedy to the Initial public offering (IPO) effect and (3) stocks with missing data, were excluded. During the study period some companies were delisted and others introduced. The final sample contained 30 listed firms and 253 firm-year observations. The financial data set was hand collected from financial reports published on the Tunisia Stock Exchange web site (www.bvmt.com.tn). Daily trading data was provided by TSE in CD-ROM and contained closing prices and trading volume.

\subsection{Variables Definition}

\subsubsection{Asset Liquidity Measures}

Financial analysts use the liquidity ratio to estimate the firm riskiness, particularly when a firm's activities are mostly funded by short-term debt (Claessens et al. 2000). Liquidity ratio is negatively associated with corporate risk in the sense that holding more cash means the firm is able to face a wider range of environmental contingencies and that more cash-constrained firms cannot do it (Cohen and al., 1972). There are three liquidity ratios commonly used in financial analysis and diagnosis of the ability of the firm to satisfy its short-term obligations (Smart and Graham, 2012).

CUR The current ratio is the most commonly cited financial ratios that define firms' ability to meet short-term obligations. It is defined as current assets divided by current liabilities.

QUR The quick ratio is similar to the current ratio except that it excludes inventory. Indeed, this latter is usually the least liquid current assets because it is typically sold on credit or cannot be easily sold.

CSR The cash ratio is defined as a company's total cash and cash equivalents to its current liabilities. The cash ratio is most commonly used as a measure of company liquidity. It can therefore, determine if, and how quickly, the company can repay its short-term debt.

${ }^{2}$ Coffee (1991) and Bhide (1993) and Maug (1998) 


\subsubsection{Stock Liquidity Measure}

The turnover-adjusted number of days with zero trading volume is proposed by Liu (2006) as a multidimensional measure of liquidity. It captures the three dimensions of liquidity: the continuity of trading and the potential delay or difficulty in executing an order, the dimension of trading quantity, i.e. volume, and the tradingcost dimension of liquidity (Liu, 2006).

It's written: $L I U_{x}=\operatorname{NoZV}_{x}+\frac{1 / T U R N_{x}}{\text { Deflator }} \frac{21 x}{\text { NoTD }}$

where $N o Z V$ is the number of zero-volume trading days; TURN is the stock turnover, i.e., the ratio of shares traded per day to outstanding shares, and NoTD is the total number of trading days in the market during the period $x$.

In line with Liu (2006), a deflator is chosen in a way that the following condition is satisfied for all stocks in the sample:

$0<\frac{1 / T U R N_{x}}{\text { Deflator }}<1$

A deflator of 3500000 to construct $L I U_{12}$ (the average number of trading days in a year) was used. The ratio $\frac{21 x}{\text { NoTD }}$ standardizes the number of trading days in a month to 21 to make it comparable over time. In other words, it measures the average number of trading days in $x$ months.

\subsubsection{Control variables}

Common control variables for cash holding regressions include:

MTB Investment opportunities measured by market-to-book assets ratio. Opler et al. (1999) show that firms having high growth opportunities, hold more cash.

SIZE The firm size is measured by total assets, which indicates the firm's ability to accede financial markets. Small firms are more financially constrained than large ones (Fazzari and Petersen, 1993). Hence, small firms are more incited to hold cash.

ROA Firm performance is considered as cash holdings' determinant. Some studies (among others Hager, 1976 and Kamath, 1989 and Jose et al. 1996) point out the negative association between cash holdings and firms' performance; firms that have less cash usually have better operating performance. In contrast, Czyzewski and Hicks (1992) show a positive association between cash and performance. They advance that successful firms have a high level of liquidity assets, which can actually produce higher than average ROA.

According to Loukil and Yousfi (2013), owner identity matters more than ownership concentration for Tunisian firms. They show that there are three types of owners: foreign, State and family owners. Thus, three dummy variables were used to distinguish between these owners and are defined as follows:

$\mathbf{F A M}= \begin{cases}1 & \text { if the first ultimate owner is family } \\ 0 & \text { otherwise }\end{cases}$

$\mathbf{S T A}= \begin{cases}1 & \text { if the first ultimate owner is the State } \\ 0 & \text { otherwise }\end{cases}$

$\mathbf{F O R}= \begin{cases}1 & \text { if the first ultimate owner is the foreign investor } \\ 0 & \text { otherwise }\end{cases}$ 
In regressions, the dummy variable reflects the presence of State control as the reference group were excluded.

Since industrial and basic material industries are expected to invest more on fixed assets, the two industry dummies included are as follows:

INDS This variable takes the value of 1 if the firm belongs to industrial industry and zero otherwise.

MBAS This variable takes the value of 1 if the firm belongs to material base industry and zero otherwise.

Table 1. Variables And Measure' Definitions

\begin{tabular}{clll}
\hline Variables & & Symbol & \multicolumn{1}{c}{ Definitions } \\
\hline \multirow{3}{*}{ Asset liquidity } & Current ratio & CUR & Current assets divided by current liabilities. \\
\cline { 2 - 4 } Stock liquidity & Quick ratio & QUR & (Current assets-inventory) divided by current liabilities \\
\cline { 2 - 4 } & Cash ratio & CSR & Total cash and cash equivalents to its current liabilities. \\
\hline \multirow{3}{*}{$\begin{array}{c}\text { Control } \\
\text { variables }\end{array}$} & Firm size & LIU & $\begin{array}{l}\text { The turnover-adjusted number of days with zero trading volume } \\
\text { proposed by Liu (2006) }\end{array}$ \\
\cline { 2 - 4 } & Investment opportunities & MTB & Total assets \\
\cline { 2 - 4 } & Performance & ROA & Return on assets \\
\cline { 2 - 4 } & FOR & $\begin{array}{l}\text { This variable takes the value of 1 if firms are controlled by } \\
\text { foreign investor and zero otherwise. }\end{array}$ \\
\cline { 2 - 4 } & Industry dummies & FAM & $\begin{array}{l}\text { This variable takes the value of 1 if firms are controlled by } \\
\text { family and zero otherwise. }\end{array}$ \\
\cline { 2 - 4 } & INDS & $\begin{array}{l}\text { This variable takes the value of 1 if firm belongs to industrial } \\
\text { industry and zero otherwise. }\end{array}$ \\
\cline { 2 - 4 } & MBAS & $\begin{array}{l}\text { This variable takes the value of 1 if firm belongs to material } \\
\text { base industry and zero otherwise. }\end{array}$ \\
\hline
\end{tabular}

\subsection{Descriptive Statistics}

Table 2 presents descriptive statistics of asset liquidity measures, stock liquidity and firm characteristics. Statistics (see Panel A) indicate that non-financial Tunisian firms have, on average, enough cash to meet short term obligation when they transform current assets on liquidity (CUR> 1 and QUR $>1$ ). As previously defined, the quick ratio is a more conservative proxy of liquidity than the current ratio as it removes inventory from the current assets used in the ratio formula. By excluding inventory, the quick ratio focuses on the more-liquid assets of a company. On average, the current ratio is significantly higher than quick ratio, which means that the company's current assets are dependent on inventory. Statistics indicate that on average, firms are unable to repay short term debt $(\mathrm{CRS}<1)$. Hence, this ratio demonstrates the importance of accounts receivable in the composition of the company's current assets. All liquidity assets variables experience a high deviation, which may be due to the heterogeneity of the study's sample.

On average, Tunisian firms have a 72 non trading days with a high deviation (74 days). This result is not surprising because the sample included firms listed in both trading systems: fixing and continuous. The less liquid stocks are traded in fixing mode and the most liquid ones are traded in a continuous one. The market to book ratio (MTB) is, on average 2.53 deviates, which is high by 12.11 , indicates that the sample is composed of firms with very high investment opportunities and other ones with low investment opportunities.

On average, Tunisian firms have a return on assets ratio (ROA) of $4.95 \%$ which deviates highly with $7.59 \%$.

Regarding ultimate owner's identity (see Panel B), Tunisian firms are highly concentrated and that only one observation presents dispersed ownership. The most frequent type of owner is the State (STA) with $45 \%$ of observations (firms-years). For the industry dummies included in the analysis (See Panel B), statistics show that $23 \%$ of observations belong to industrial industry and $16 \%$ of observations belong to material basis industry, while $61 \%$ of observations belong to the consumer goods and services industry(oil and gas, and telecommunications industries). 
Table 2. Descriptive Statistics

\begin{tabular}{|c|c|c|c|c|c|c|c|}
\hline \multicolumn{8}{|c|}{ Panel A. Asset liquidity, stock liquidity and other financial characteristics variables } \\
\hline & CUR & QUR & CRS & LIU & MTB & SIZE & ROA \\
\hline $\mathbf{N}$ & 244 & 244 & 244 & 227 & 227 & 227 & 227 \\
\hline Mean & 2,4256 & 1,7281 & 2908 & 72,55 & 2,534 & $1,28 \mathrm{E}+08$ & 0495 \\
\hline Median & 1,7194 & 1,0997 & ,0956 & 42,33 & 1,171 & $5,06 \mathrm{E}+07$ &, 0454 \\
\hline Std. Deviation & 2,33543 & 2,27857 & 68363 & 74,124 & 12.11 & $2,79 E+08$ & 0759 \\
\hline Skewness & 2,820 & 3,336 & 5,825 &, 772 & 12,18 & 3,916 &,- 593 \\
\hline Kurtosis & 8,731 & 12,244 & 41,214 & 2,210 & 158,22 & 17,044 & 3.994 \\
\hline Minimum &, 31 &, 16 &, 00 & ,00001 &, 1366 & $1,03 \mathrm{E}+07$ &,- 21 \\
\hline Maximum & 14,24 & 14,18 & 6,40 & 252,00 & 167,17 & $1,49 \mathrm{E}+09$ &, 24 \\
\hline
\end{tabular}

\begin{tabular}{lcc}
\hline \multicolumn{3}{l}{ Panel B. Frequency of ultimate owners and industry dummies } \\
\hline Ultimate owner types & $\mathbf{N}$ & $\%$ \\
Dispersed & 1 & $0.4 \%$ \\
FOR & 28 & $11.5 \%$ \\
FAM & 104 & $42.6 \%$ \\
STA & 111 & $45.5 \%$ \\
Total observations & 244 & \\
& & \\
\hline Industry & & \\
\hline INDS & 56 & $23,0 \%$ \\
MBAS & 39 & $16,0 \%$ \\
Total observations & 244 & \\
\hline
\end{tabular}

Results (see Table 3) show that quick ratio and cash ratio are negatively and significantly associated with execution delay. However, non-significant joining is detected between current ratio and Liu' measure. These correlations indicate that high stock liquidity level (short execution delay) is positively linked to high asset liquidity.

The investment opportunities variable (MTB) one side is positively correlated and significantly correlated with quick ratio and on the other is negatively and significantly mutually connected with execution delay (LIU). Firms with high levels of liquid asset, have more investment opportunities and more liquid stocks. Firm size is negatively and significantly related to asset liquidity measures (CUR and QUR) and to execution delay (LIU). Hence, large firms invest more on fixed assets than liquid assets and have more liquid stocks. Return on assets (ROA) are positively and significantly correlated with all asset liquidity measures, it's negatively and significantly correlated to Liu' measure. These correlations show that firms with high performance invest more in liquid assets and have liquid stocks.

For ultimate owner's identity, a correlation matrix indicates that foreign owner presence is positively correlated with asset liquidity ratios (CUR and QUR). Yet, the family owner presence is negatively correlated with asset liquidity ratios (CUR and CRS). Foreign controlled firms invest more in liquid assets than family controlled ones. 
Table 3. Spearman Correlation Matrix

\begin{tabular}{|c|c|c|c|c|c|c|c|c|c|}
\hline & CUR & QUR & CRS & FOR & FAM & LIU & MTB & ROA & SIZE \\
\hline CUR & 1 & & & & & & & & \\
\hline QUR &, $761^{* * *}$ & 1 & & & & & & & \\
\hline CRS &, $339^{* * * *}$ &, $494^{* * * *}$ & 1 & & & & & & \\
\hline FOR &, $210^{* * * *}$ &, $171^{* * * *}$ & 0,002 & 1 & & & & & \\
\hline FAM &,$- 176^{* *}$ & $-0,096$ &,$- 185^{* * *}$ &,$- 310^{* * * *}$ & 1 & & & & \\
\hline LIU & $-0,004$ &,$- 138^{* *}$ & $-0,131 *$ & $-0,051$ & $-0,018$ & 1 & & & \\
\hline MTB & 0,013 &, $144^{* *}$ & 0,066 &, $444^{* * *}$ & 0,077 &,$- 145^{* *}$ & 1 & & \\
\hline ROA &, $393^{* * * *}$ &, $363^{* * *}$ &, $198^{* * * *}$ &, $381^{* * *}$ & $0,115^{*}$ &,$- 147^{* *}$ &, $517^{* * * *}$ & 1 & \\
\hline SIZE &,$- 438^{* * * *}$ &,$- 184^{* * * *}$ & 0,003 &, $165^{* *}$ & $-0,117 *$ &,$- 307^{* * * *}$ & $149^{* * *}$ & $-0,118 *$ & 1 \\
\hline
\end{tabular}

*. **. *** are respectively significance level of $10 \% .5 \% .1 \%$

\section{RESULTS AND DISCUSSION}

\subsection{Basic Analysis}

The relationship between stock liquidity and asset liquidity, through a multiple regression with panel data, was studied. Thus, the following model was estimated:

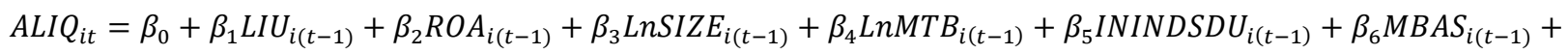
$\beta 7 F O R i(t-1)+\beta 8 F A M i(t-1)+\varepsilon i t$

Where ALIQ is one of the three asset liquidity variables: current ratio (CUR) quick ratio (QUR), cash ratio (CSR). $\varepsilon_{i t}$ is the error term of a firm $i$ at year $t$. The idea is to estimate each model three times using asset liquidity, lagged stock liquidity variables and other control variables.

Empirical findings (See Table 4) show both negative and significant coefficient of illiquidity measures on two measures of asset liquidity (current and quick ratios). These findings confirm that firms with high stock liquidity (short potential delay of executing an order) invest more on liquid assets. For this reason, accordingly hypothesis H1 is accepted and $\mathrm{H} 2$ is rejected. The results have provided empirical support for the theory of positive feedback from stock prices and have corroborated those of Nyborg and Wang (2014).

Table 4. The Impact Of Stock Liquidity On Asset Liquidity

\begin{tabular}{lccc}
\hline & CUR & QUR & CRS \\
\hline LIU & $-0.003^{* * *}$ & $-0.002^{* * *}$ & -0.003 \\
ROA & $1.833^{* * *}$ & $1.720^{* * *}$ & 1.448 \\
SIZE & $-0.342^{* * *}$ & $-0.255^{* * *}$ & -0.085 \\
MTB & -0.081 & -0.014 & 0.121 \\
FAM & $-0.341^{* * *}$ & -0.203 & $-0.607 * *$ \\
FOR & 0.075 & -0.003 & -0.848 \\
INDS & 0.089 & $-0.561 * * *$ & $-0.988^{* * *}$ \\
MABS & $0.648^{* * *}$ & $0.736^{* * *}$ & $1.018^{* *}$ \\
Constant & $6.814 * * *$ & $4.758^{* * *}$ & -0.387 \\
R squared & 0.2271 & 0.2271 & 0.1570 \\
Observations & 223 & 223 & 223 \\
Number of firms & 30 & 30 & 30 \\
\hline
\end{tabular}

*.**.*** are respectively significance level of $10 \% .5 \% .1 \%$

Indeed, high level of liquidity increases the activity of informed agents which make prices more informative to investors, employees, customers and other stakeholders. Firms with more informative prices will hold more cash than other firms. In bad situations, prices' decrease makes external funds costly for these firms, which encourages them to use cash held. While in a good situation, price increases indicate that firms are well managed, which attracts capital providers and reduces cost of capital. Firms may use their cash holding to boost positive effects of price feedback by buying their own stocks in the market. 
Results indicate both positive and significant effects of firms' performance on asset liquidity measures (at level of $1 \%$ ). Hence, firms that experience high performance invest more in liquid assets. Coefficients of firm size are negative and significant when current and quick ratio as asset liquidity measures were used. Indeed, small firms are more financially constrained and cannot accede easily to external funds like large ones, which encourages them to hold more liquid assets.

For ultimate owner's identity, only the presence of family ultimate owner has a significant and negative coefficient on current ratio and cash ratio. Whereas, for quick ratio none ultimate owner proxies have a significant effect. It indicates that firms controlled by family owners, invest less in liquid assets than firms controlled by foreign and State owners. These findings confirm the influence of owner's identity on financial corporate decisions. As far as industry dummy variables are concerned, a negative and significant coefficient of INDS on two measures of asset liquidity (quick and cash ratios) are found. In addition, results show positive and significant coefficients of MBAS on all regressions. Hence, industry types influence the level of asset liquidity.

\subsection{Robustness Analysis}

In order to check the robustness of the previous results, the stock price informativeness on asset liquidity measures regressed. Firms with more informative prices are more transparent for their stakeholders. On the one part, when these firms have a positive feedback prices, they can enjoy reduced cost of capital and use internal funds and liquidity to boost the positive feedback prices. On the other part, when firms have negative feedback prices, they must use internal funds because the cost of capital is high. In the two situations, firms with more informative prices hold more cash. Therefore, the hypothesis 3 is stated as follow:

\section{H3: The more informative the prices are, the more firms do hold cash.}

To estimate price informativeness, the proportion of zero returns proposed by Lesmond et al. (1999) was used and defined as follows:

$P Z E R=\frac{\text { number of zero return }}{N}$

Where $\mathrm{N}$ is the number of trading day per year.

They advance that investors will not trade unless the value of their private information is sufficient to exceed their trading costs. If the informed investors do not trade, then there is no change in price, and zero-return results. Zero returns may be due to the absence of new information. Similar to Skaife et al. (2006), it is considered that a lower proportion of zero-return days reflects the high frequency of a firm's information flow.

Table 5. Price Informativeness And Asset Liquidity

\begin{tabular}{lccc}
\hline & CUR & QUR & CRS \\
\hline PZER & $-0.008^{* * *}$ & $-0.009^{* * *}$ & $-0.010^{*}$ \\
ROA & $1.561^{* * *}$ & $1.474^{* *}$ & 1.220 \\
SIZE & $-0.349^{* * *}$ & $-0.274 * * *$ & -0.110 \\
MTB & -0.082 & -0.030 & 0.105 \\
FAM & $-0.303^{* * *}$ & -0.177 & $-0.581^{* *}$ \\
FOR & 0.104 & 0.023 & -0.815 \\
INDS & 0.096 & $-0.548^{* * *}$ & $-0.976^{* * *}$ \\
MABS & $0.657^{* * *}$ & $0.797 * * *$ & $1.067^{* * *}$ \\
Constant & $7.099^{* * *}$ & $5.309 * * *$ & 0.285 \\
R squared & 0.4010 & 0.2357 & 0.1591 \\
Observations & 223 & 223 & 223 \\
Number of firms & 30 & 30 & 30 \\
\hline
\end{tabular}

*.**.*** are respectively significance level of $10 \% .5 \% .1 \%$

Empirical findings indicate the robustness of previous ones and hypothesis $\mathrm{H} 3$ is accepted. There is a negative and significant relationship between the proportion of zero return and asset liquidity variables. A higher 
proportion of zero return, indicating lower price informativeness, discourages firms to hold cash. Results also indicate that the R squared values (see table 5) are higher than those of the basic regressions (see table 4). Hence, price informativeness (PZER) determines more asset liquidity than illiquidity measure (LIU). These finding provide evidence that stock prices influence firms' cash policy through stock liquidity.

\section{CONCLUSION}

This paper investigated whether or not feedback prices influence corporate cash holdings through stock liquidity in emerging market. The results confirm the existence of a link between stock liquidity and firm's decisions. In other words, stock liquidity enhances firms' investment in liquid assets through a feedback prices effect. Indeed, high stock liquidity increases stock price informativeness. As a consequence, firms are incited to hold more cash to overcome negative feedback prices and to enjoy benefits from positive feedback prices. In the present study, only causality effect of stock liquidity on corporate decisions was examined, which explains why lagged stock liquidity variables were used. However, corporate decisions and stock liquidity may have a joint causality effects. In fact, Nyborg and Wang's (2014) study confirms the existence of a simultaneous relationship between stock liquidity and asset liquidity. It would be interesting to discover, in future studies, the joint effects between corporate decisions and stock liquidity.

\section{AUTHOR INFORMATION}

Dr. Nadia Loukil is an associate Professor of Finance at he ESSEC Tunis, University of Tunis. She is affiliated to the research laboratory "Gouvernance d'Entreprise, Finance Appliquée et Audit (GEF2A), University of Tunis. Her research interests are financial markets, market liquidity, ownership structure, corporate governance and corporate finance. Her researches have been published in Macroeconomics and Finance in emerging market economies, Journal of Accounting in Emerging Economies, International Journal of corporate governance and Bankers Markets and Investors Journal. Corresponding email: nadialoukil@gmail.com

\section{REFERENCES}

Admati, A. R., and Pfleiderer, P. (2009). The "Wall Street Walk" and shareholder activism: Exit as a form of voice. Review of Financial Studies, 22 (7)M 2645-2685.

Amihud, Y. and Mendelson, H. (1986), “Asset pricing and the bid-ask spread”, Journal of Financial Economics, 17 (2), 223-249.

Ben Khediri, K. and Daadaa, W. (2011) “ Stock trading and capital structure in Tunisian stock exchange.” Journal of Business Studies Quarterly. 3(2), 10-24.

Bhide, A. (1993). The hidden costs of stock market liquidity. Journal of Financial Economics, 34(1), 31-51.

Butler, A. W., Grullon, G. and Weston, J. P.(2005). Stock Market Liquidity and the Cost of Issuing Equity. Journal of Financial and Quantitative Analysis 40(2), 331-348.

Coffee, J. C. (1991). Liquidity versus control: The institutional investor as corporate monitor. Columbia Law Review, 1277-1368.

Czyzewski, A.B., and D.W. Hicks. (1992). Hold Onto Your Cash. Management Accounting. 27, 30.

Diamond, D. and Verrecchia R. (1982).Optimal managerial contracts and equilibrium security prices. Journal of Finance, 37(2), 275-287

Dittmar, A., Mahrt-Smith, J., Servaes, H. (2003). International corporate governance and corporate cash holdings. Journal of Financial and Quantitative Analysis 38 (1),111-133.

Edmans, A. (2009). Blockholder trading, market efficiency, and managerial myopia. The Journal of Finance, 64 (6), 2481-2513.

Fang, V. NOE W.,, Thomas H., and TICE, S. (2009), Stock market liquidity and firm value. Journal of Financial Economics, 94 (1), 150-169.

Fazzari, S.M. and Petersen, B. (1993). Working capital and fixed investment: new evidence on financing constraints, Rand Journal of Economics 24 (3), 328-342

Goldstein, I., Ozdenoren, E., and Yuan, K. (2013).Trading frenzies and their impact on real investment. Journal of Financial Economics, 109 (2), 566-582

Hager, H. C. (1976). Cash management and the cash cycle. Management Accounting, 57(9),19-21. 
Han, S., \& Qiu, J. (2007), “Corporate precautionary cash holdings”. Journal of Corporate Finance, Vol.13 No.1, pp. 43-57.

Holmstrom, B. andTirole J. (1993). Market liquidity and performance monitoring. Journal of Political Economy, 101(4), 678-709

Jose, M.L., Lancaster, C. and Stevens, J.L. (1996).Corporate returns and cash conversion cycles. Journal of Economics and Finance, 20(1),33-46.

Kamath, R. (1989). How useful are common liquidity measures. Journal of Cash Management, 9 (1), 24-28.

Khanna, N., and Sonti, R. (2004), Value creating stock manipulation: feedback effect of stock prices on firm value. Journal of Financial Markets, 7 (3), 237-270.

Lagoarde-Segot, T., and Lucey, B. M. (2008). Efficiency in emerging markets-Evidence from the MENA region, Journal of International Financial Markets, Institutions and Money, 18 (1), 94-105

Lesmond, D. A., Ogden, J. P., and Trzcinka, C. A. (1999). A new estimate of transaction costs. Review of Financial Studies, $12(5), 1113-1141$.

Lins, K. V., Servaes, H., and Tufano, P. (2010). What drives corporate liquidity? An international survey of cash holdings and lines of credit. Journal of Financial Economics, 98 (1),160-176.

Lipson, M.L. and Mortal, S. (2009), Liquidity and capital structure. Journal of Financial Markets 12 (4), 611-644.

Liu, W. (2006). A liquidity-augmented capital asset pricing model. Journal of Financial Economics 82 (3), 631-671.

Loukil N. and Yousfi O. (2013). Does corporate governance affect stock liquidity in the Tunisian Stock Market?. Banks Markets \& Investors, Juillet-Août,125, 35-53.

Maug, E. (1998). Large Shareholders as Monitors: Is There a Trade-Off between Liquidity and Control?. The Journal of Finance, 53 (1), 65-98.

Munoz, F. (2013). Liquidity and firm investment: Evidence for Latin America. Journal of Empirical Finance, 20,1829.

Myers, S. C. and Majluf, N. S. (1984). Corporate financing and investment decisions when firms have information that investors do not have. Journal of Financial Economics, 13 (2), 187-221.

Myers, S.C. (1984). The capital structure puzzle. The Journal of Finance, 39 (3), 575-592.

Nyborg, K. G., and Wang, Z. (2014). Stock liquidity and corporate cash holdings: Feedback and the Cash as Ammunition Hypothesis. Swiss Finance Institute Research Paper Series N ${ }^{\circ} 13-36$ Available at: http://papers.ssrn.com/sol3/papers.cfm?abstract_id=2285535

Opler, T., Pinkowitz, L., Stulz, R., and Williamson, R. (1999). The determinants and implications of corporate cash holdings. Journal of Financial Economics, 52(1), pp.3-46.

Skaife, H. A., Gassen, J., and LaFond, R. (2006). Does stock price synchronicity represent firm-specific information? The international evidence. MIT Sloan Research Paper No. 4551-05. Available at SSRN: http://ssrn.com/abstract=768024 or http://dx.doi.org/10.2139/ssrn.768024

Smart, S. B. and Graham, J. R. (2012). Introduction to financial management. South-Western Cengage Learning.

Subrahmanyam, A., and Titman, S. (2001). Feedback from stock prices to cash flows. The Journal of Finance 56(6), 2389-2413.

Sufi, A. (2009). Bank lines of credit in corporate finance: An empirical analysis. Review of Financial Studies 22 (3), 1057-1088 